\title{
PENGARUH METODE PEMBELAJARAN DALAM JARINGAN TERHADAP HASIL BELAJAR MAHASISWA PERAWAT SELAMA MASA AWAL PANDEMI COVID-19
}

\author{
The Effect of Online Learning Methods on Nursing Student Learning Outcomes During \\ Early Period of COVID-19 Pandemic
}

\author{
Gede Arya Bagus Arisudhana ${ }^{\mathbf{1}}$, Nyoman Eta Risnawati ${ }^{2}$ \\ ${ }^{1,2}$ Departemen Keperawatan Medikal Bedah, STIKES Bina Usada Bali, Badung, Bali, Indonesia \\ Korespondensi : aryabagus08@gmail.com
}

\begin{abstract}
ABSTRAK
Pandemi COVID-19 berdampak pada proses pembelajaran di Indonesia, untuk itu pemerintah menetapkan kebijakan model pembelajaran jarak jauh melalui metode dalam jaringan. Perlu dilakukan evaluasi terhadap efektivitas metode ini pada proses pembelajaran keperawatan dengan menilai hasil belajar mahasiswa. Penelitian ini bertujuan untuk mengetahui pengaruh metode pembelajaran dalam jaringan terhadap hasil belajar mahasiswa perawat selama masa awal pandemi COVID-19. Desain penelitian yang digunakan adalah pendekatan one group post test only. Populasi terjangkau dalam penelitian ini adalah mahasiswa keperawatan semester 4 di STIKES Bina Usada Bali. Jumlah sampel dalam penelitian ini sebanyak 68 orang dengan teknik pengambilan sampel menggunakan purposive. Pengumpulan data hasil belajar mahasiswa menggunakan lembar penilaian mata kuliah. Analisa data menggunakan uji one sample t. Hasil penelitian ini menunjukkan ratarata nilai mahasiswa pada mata kuliah keperawatan HIV/AIDS adalah 69,09, dengan nilai thitung 10,6 $>$ t-tabel 1,996 dengan nilai $\mathrm{p}=0,000$ sig.(2-tailed) $<0,05$. Dapat disimpulkan bahwa ada pengaruh metode pembelajaran dalam jaringan terhadap hasil belajar mahasiswa perawat selama masa awal pandemi COVID-19, nilai rata-rata hasil belajar mahasiswa keperawatan pada mata kuliah keperawatan HIV/AIDS tidak sama dengan nilai 65. Untuk itu identifikasi yang dilakukan sejak dini perlu dilakukan guna kefektifan pemberian asuhan keperawatan.
\end{abstract}

Kata Kunci: daring, pandemi, COVID-19

\section{ABSTRACT}

The COVID-19 pandemic has an impact on the learning process in Indonesia. For this reason, the government establishes a distance learning model policy through online methods. It is necessary to evaluate the effectiveness of this method in the nursing learning process by assessing student learning outcomes. This study aims to determine the effect of online learning methods on nursing student learning outcomes during the early days of the COVID-19 pandemic. The research design used was a one group post test only approach. The affordable population in this study were the fourth semester nursing students at STIKES Bina Usada Bali. The number of samples in this study were 68 people with a purposive sampling technique. Collecting data on student learning outcomes using course assessment sheets. Data analysis using one sample t-test. The results of this study showed that the average score of students in the HIV / AIDS nursing course was 69.09, with a t-count value of 10.6>t-table 1.996 with a value of $p=0.000$ sig. (2-tailed) $<0.05$. It can be concluded there was an effect of online learning methods on nursing student learning outcomes during the early days of the COVID-19 pandemic, the average score of nursing student learning outcomes in the HIV / AIDS nursing course is not the same as the value of 65. For this reason, early identification is necessary for the effectiveness of providing nursing care. 
Keywords: online, pandemic, COVID-19 PENDAHULUAN

Penyebaran coronavirus disease 19

(COVID-19) keseluruh wilayah dunia mengakibatkan penetapan status pandemi global diberlakukan WHO sejak pertengahan Maret tahun 2020. Dengan merebaknya kasus terjangkit positif COVID19 pada manusia di seluruh dunia berdampak pada pendekatan budaya komunikasi dan sosialisasi antar individu. Guna memutus rantai penyebaran COVID19 dari manusia ke manusia maka dilakukan pendekatan social \& physical distancing hingga memberlakukan status karantina wilayah (lock down) (Lau et al., 2020). Di Indonesia penyebaran COVID-19 terjadi secara sporadis diawal tahun 2020, namun dengan waktu yang singkat semakin banyak masyarakat Indonesia yang terinfeksi COVID-19. Dilaporkan dari 31 Provinsi di Indonesia, jumlah terkonfirmasi positif COVID-19 mencapai 1.414 orang pada akhir Maret 2020 (Damarjati, 2020b). Di bulan April 2020 kasus terjangkit COVID19 terus mengalami peningkatan dengan angka kejadian mencapai 10.118 kasus, serta jumlah orang yang meninggal dunia mencapai 792 orang (Damarjati, 2020a).

Dengan meluasnya pandemi COVID-

19 diseluruh wilayah Indonesia maka pemerintah menetapkan strategi pembatasan aktifitas berkumpul, termasuk proses belajar-mengajar di sekolah maupun universitas seperti yang tertuang dalam Peraturan Menteri Kesehatan Nomor 9 tahun 2020 (Kementerian Kesehatan RI, 2020). Situasi pandemi mengharuskan pemerintah menetapkan kebijakan yang efektif dalam menjaga kualitas dan hasil pembelajaran mahasiswa melalui program Belajar Dari Rumah (BDR). Program BDR ditetapkan sebagai pembelajaran jarak jauh, untuk itu seluruh perguruan tinggi di Indonesia wajib melakukan modifikasi proses belajarmengajar melalui metode online atau dalam jaringan (Kementerian Pendidikan dan Kebudayaan RI, 2020).

Metode pembelajaran dalam jaringan (daring) memiliki banyak model dan metode pendekatan. Hal ini menjadi tantangan bagi lembaga pendidikan tinggi dalam mengembangkan model pembelajaran daring, khususnya pada program pendidikan keperawatan sehingga hasil belajar mahasiswa tetap berada pada kualitas terbaik. Beberapa penelitian menemukan terdapat efek yang merugikan pada model belajar daring dibandingkan dengan model belajar tradisional di luar jaringan (luring) (Figlio, Rush, \& Yin, 2013; Xu \& Jaggars, 2013). Xu \& Jaggars (2013), menemukan sebagian besar penggunaan model belajar daring memiliki efek yang merugikan pada siswa laki-laki, siswa yang berusia lebih muda, dan siswa dengan hasil belajar yang rendah. Temuan lainnya pada penggunaan model daring didapatkan bahwa siswa dapat mengikuti kuliah secara daring dengan menggunakan akun dari rekan lainnya yang tergabung secara daring (Nguyen, 2015).

Beberapa penelitian telah menemukan efek negative pemanfaatan model daring pada hasil belajar siswa dan/atau mahasiswa. Berdasarkan pernyataan empiris tersebut maka penelitian tentang penerapan model belajar daring pada mahasiswa keperawatan perlu dilakukan, untuk mengetahui hasil belajar mahasiswa perawat selama satu semester pada masa pandemi COVID-19 dengan menggunakan model daring.

\section{TUJUAN PENELITIAN}

Tujuan pelaksanaan penelitian ini adalah untuk mengetahui pengaruh metode pembelajaran dalam jaringan terhadap hasil belajar mahasiswa perawat selama masa awal pandemi COVID-19.

\section{METODE PENELITIAN \\ Desain}

Penelitian ini menggunakan desain kuantitatif dengan pendekatan penelitian pra eksperimen one group post test only.

\section{Populasi dan Sampel}

Populasi terjangkau pada penelitian ini adalah seluruh mahasiswa keperawatan di STIKES Bina Usada Bali. Sampel penelitian ini adalah mahasiswa tingkat 2 semester 4 tahun akademik 2019/2020. Jumlah sampel dalam penelitian ini adalah 
Gede Arya Bagus Arisudhana, dkk: Pengaruh Metode Pembelajaran Dalam Jaringan Terhadap Hasil Belajar Mahasiswa Perawat Selama Masa Awal Pandemi Covid19

68 orang. Teknik pengambilan sampel menggunakan purposive sampling. Kriteria inklusi sampel dalam penelitian ini adalah mahasiswa sudah mendapat mata kuliah keperawatan medikal bedah 1, mahasiswa bersedia mengikuti perkuliahan daring selama 14 kali tatap muka, mahasiswa menggunakan peralatan daring mandiri. Kriteria inklusi dalam penelitian ini adalah mahasiswa yang mengikuti kuliah dengan menonaktifkan tampilan camera, mahasiswa tidak bersedia menjadi responden. Kriteria drop out dalam penelitian ini adalah mahasiswa yang mengalami gangguan jaringan sehingga tidak dapat mengikuti kuliah daring secara efektif.

\section{Tempat dan Waktu Penelitian}

Penelitian ini bertempat di STIKES Bina Usada Bali dan pelaksanaan penelitian dilakukan selama 6 bulan.

\section{Intervensi}

Intervensi yang diberikan adalah berupa penggunaan metode pembelajaran daring selama 14 kali tatap muka selama 1 semester pada mata kuliah keperawatan HIV/AIDS.

\section{Instrumen dan Prosedur Pengukuran}

Instrumen yan digunakan dalam pengukuran hasil belajar mahasiswa adalah paket soal sebanyak 60 pertanyaan pada mata kuliah keperawatan HIV/AIDS. Pengukuran dilakukan pada akhir semester.

\section{Analisa Data}

Analisa data menggunakan analisa univariat yang dilakukan adalah mencari nilai mean, median, standar deviasi, nilai minimum, nilai maksimum. Analisa bivariate menggunakan analisa one sample $t$ test dengan sebelumnya menggunakan uji validitas data dengan uji kolmogorovsmirnov pada variabel hasil belajar mahasiswa.

\section{HASIL PENELITIAN}

Hasil penelitian ini akan disajikan dalam bentuk tabel sebagai berikut:

\section{Tabel 1}

Hasil Belajar Mahasiswa Perawat $(\mathrm{n}=68)$

\begin{tabular}{cccc} 
Mean \pm SD & Median & Min & Max \\
\hline $69.09 \pm 3.2$ & 69.2 & 61.1 & 78.2 \\
\hline
\end{tabular}

Berdasarkan tabel 1, dapat diketahui hasil belajar mahasiswa memperoleh ratarata nilai 69,09 dengan standar deviasi 3,2. Untuk median diketahui 69,2, dengan nilai minimum 61,1 dan nilai maksimum 78,2.

Tabel 2

Pengaruh Metode Daring Terhadap Hasil Belajar Mahasiswa Perawat $(n=68)$

\begin{tabular}{cccc}
\hline Variabel & $\mathrm{T}_{\text {hitung }}$ & $\mathrm{T}_{\text {tabel }}$ & Nilai $\mathrm{p}$ \\
\hline $\begin{array}{c}\text { Hasil } \\
\text { Belajar }\end{array}$ & 10,6 & 1,996 & 0,000 \\
Mahasiswa & & & \\
\hline \multicolumn{2}{c}{ Berdasarkan } & hasil & perhitungan
\end{tabular}

statistik pada tabel 2, diketahui nilai t-hitung $10,6>\mathrm{t}$-tabel 1,996 dengan nilai $\mathrm{p}=0,000$ sig. (2-tailed) $<0,05$, dengan demikian dapat disimpulkan nilai rata-rata hasil belajar mahasiswa keperawatan pada mata kuliah keperawatan HIV/AIDS tidak sama dengan nilai 65. Berdasarkan hasil uji hipotesis tersebut diketahui terdapat pengaruh metode pembelajaran dalam jaringan terhadap hasil belajar mahasiswa perawat selama masa awal pandemi COVID-19.

\section{PEMBAHASAN}

Hasil belajar mahasiswa dapat dipengaruhi oleh metode pengajaran yang digunakan. Hasil penelitian ini menunjukkan rata-rata hasil belajar mahasiswa pada mata kuliah keperawatan HIV/AIDS tidak sama dengan nilai standar 65 , diketahui rata-rata nilai adalah 69,09 , dimana rata-rata nilai lebih tinggi dari nilai standar yang telah ditetapkan. Temuan dalam penelitian ini sejalan dengan hasil penelitian ZaragozaGarcía, Pérez-García, Orellana-Miguel, Posé-Becerra, \& Goñi-Olangua (2019) menemukan bahwa pembelajaran dengan metode daring dapat meningkatkan pengetahuan tentang prosedur klinis dan dapat diterapkan dalam praktik klinik.

Metode pembelajaran daring dapat membantu mahasiswa keperawatan dalam kemudahan mengakses lebih banyak 
informasi dan materi yang disampaikan saat pembelajaran daring dapat diakses darimana saja. Hal ini akan membantu meningkatkan tanggungjawab mahasiswa dalam proses pembelajarannya sendiri serta pembentukan karakter, sehingga pembelajaran daring merupakan model pembelajaran orang dewasa dan pembelajaran mandiri. Hal ini dikemukakan oleh Baghaie \& Atrkar Roushan (2003) yang menyebutkan bahwa orang dewasa dapat efisien belajar dengan metode yang diarahkan sendiri. Pendekatan belajar mengajar, termasuk model daring dicetuskan berdasarkan teori tersebut. Melalui pembelajaran daring, peserta didik dimungkinkan mencapai tujuan pendidikan berdasarkan bakat mereka (Zolfaghari, Mehrdad, \& Asadi, 2011).

Penelitian lain menemukan bahwa pembelajaran dengan metode daring berbasis e-learning terbukti meningkatkan kreatifitas dan kemampuan belajar mahasiswa perawat (Mahmoodi, Maleki, \& Sanisales, 2015). Sejalan dengan temuan penelitian tersebut, dalam peneletian ini mahasiswa perawat lebih kreatif dalam melakukan penelusuran materi pembelajaran yang dipaparkan oleh para pengajar, selain itu mahasiswa tampak aktif dalam bertanya untuk meningkatkan kemampuan dalam penguasaan materi pembelajaran, sehingga melalui proses tersebut dapat meningkatkan hasil belajar mahasiswa.

Penilaian hasil belajar mahasiswa dapat dilakukan dengan memperhatikan beberapa indikator seperti peningkatan pengetahuan, sikap, keaktifan, kreatifitas, dan inovasi yang dilakukan oleh mahasiswa dengan kata lain penilaian dilakukan dengan melihat ranah afektif, kognitif, maupun psikomotor dari mahasiswa perawat.

\section{KESIMPULAN}

Implikasi

Hasil penelitian ini dapat disimpulkan bahwa terdapat pengaruh metode pembelajaran dalam jaringan terhadap hasil belajar mahasiswa perawat selama masa awal pandemi COVID-19, yang ditunjukkan dengan rata-rata nilai hasil belajar mahasiswa pada mata kuliah keperawatan HIV/AIDS tidak sama dengan nilai standar 65 , dengan rata-rata nilai adalah 69,09. Pemanfaatan model pembelajaran ini dapat meningkatkan kemandirian dalam belajar mahasiswa, tingkat kreatifitas serta kemudahan dalam pembelajaran. Model pembelajaran daring dapat mempersingkat jarak, meminimalkan biaya, dan fleksibilitas dalam proses belajar-mengajar.

\section{Keterbatasan}

Pada penelitian ini terdapat beberapa keterbatasan dalam proses pelaksanaan pembelajaran secara daring seperti pengajar kesulitan dalam memanajemen masalah teknis diataranya masalah jaringan yang mengakibatkan penerimaan saat proses pembelajaran berlangsung tidak efektif. Selain itu, pembiayaan pembelian kuota internet menambah biaya operasional pendidikan mahasiswa.

\section{DAFTAR PUSTAKA}

Baghaie, M., \& AtrkarRoushan, Z. (2003). A Comparision of two teaching strategies: Lecture and PBL, on learning and retaining in nursing students. Journal of Guilan University of Medical Sciences, 12(47), 86-94.

Damarjati, D. (2020a). Data Corona Terkait Indonesia, 30 April 2020 Per Pukul 16.00 WIB. Retrieved March 3, 2021, from https://news.detik.com/berita/d4997618/data-corona-terkait-indones ia-30-april-2020-per-pukul-1600-wib

Damarjati, D. (2020b). Data Corona Terkait Indonesia, 31 Maret 2020 Pukul 16.30 WIB. Retrieved March 3, 2021, from https://news.detik.com/berita/d-49599 74/data-corona-terkait-indonesia-31-m aret-2020-pukul-1630-wib

Figlio, D., Rush, M., \& Yin, L. (2013). Is it live or is it internet? experimental estimates of the effects of online instruction on student learning. Journal of Labor Economics, 31(4), 763-784.

Kementerian Kesehatan RI. Peraturan Menteri Kesehatan Republik Indonesia Nomor 9 tahun 2020 Tentang Pedoman 
Gede Arya Bagus Arisudhana, dkk: Pengaruh Metode Pembelajaran Dalam Jaringan Terhadap Hasil Belajar Mahasiswa Perawat Selama Masa Awal Pandemi Covid19

Pembatasan Sosial Berskala Besar Learning, ICEL, 49(5), 474-480. Dalam Rangka Percepatan Penangan Corona Virus Disease 2019 (COVID19), Pub. L. No. 9/2020 (2020). Indonesia.

Kementerian Pendidikan dan Kebudayaan RI. (2020). Surat Edaran Nomor 4 Tahun 2020 Tentang Pelaksanaan Kebijakan Pendidikan Dalam Masa Darurat Penyebaran Coronavirus Disease (COVID-19). Jakarta: Kementerian Pendidikan dan Kebudayaan RI.

Lau, H., Khosrawipour, V., Kocbach, P., Mikolajczyk, A., Schubert, J., Bania, J., \& Khosrawipour, T. (2020). The positive impact of lockdown in Wuhan on containing the COVID-19 outbreak in China. Journal of Travel Medicine, 27(3), 1-7.

Mahmoodi, M. T., Maleki, S., \& Sanisales, Z. (2015). The Impact of E-Learning on Creativity and Learning in Physiology Course in Nursing Students of Shahrekord University of Medical Sciences. Future of Medical Education Journal, 5(4), 25-29.

Nguyen, T. (2015). The Effectiveness of Online Learning: Beyond No Significant Difference and Future Horizons. MERLOT Journal of Online Learning and Teaching, 11(2), 309319.

Xu, D., \& Jaggars, S. S. (2013). Adaptability to online learning: Differences across types of students and academic subject areas (No. 54). Community College Research Center. New York.

Zaragoza-García, I., Pérez-García, S., Orellana-Miguel, M. de los Á., PoséBecerra, C., \& Goñi-Olangua, M. A. (2019). The effectiveness of an online training program in a nursing unit: Extraction of blood cultures. Revista Da Escola de Enfermagem, 53, 1-8.

Zolfaghari, M., Mehrdad, N., \& Asadi, A. A. (2011). Learning outcomes in two different nursing educational approaches in Iran: ELearning versus lecture. Proceedings of the International Conference on $E$ - 